\title{
Bank Capital Requirements and Collateralised Lending Markets
}

\author{
Margarita Rubio* \\ José A. Carrasco-Gallego ${ }^{\dagger}$ \\ University of Nottingham \\ University of Portsmouth
}

September 2016

\begin{abstract}
In this paper, we take as a baseline a dynamic stochastic general equilibrium (DSGE) model, which features a housing market, borrowers, savers and banks, in order to evaluate the welfare and macroeconomic effects of the new fixed capital requirements in the Basel accords. Our results show that the higher capital requirements imposed by Basel I, II and III decrease both the quantity of borrowing and its variability, producing distributional welfare effects among agents: savers are better off, but borrowers and banks are worse off. Then, we propose a macroprudential rule for the countercyclical capital buffer of Basel III in which capital requirements respond to credit growth, output and housing prices. We find that the optimal implementation of Basel III is countercyclical for borrowers and banks, the agents directly affected by capital requirements, while procyclical for savers. From a normative perspective, we see that this macroprudential rule for Basel III delivers higher welfare for the society than a situation with no regulation.
\end{abstract}

Keywords: Basel I, Basel II, Basel III, banking regulation, welfare, banking supervision, macroprudential, capital requirement ratio, credit, countercyclical capital buffer.

JEL Classification: E32, E44, E58

\footnotetext{
*University of Nottingham, University Park, Sir Clive Granger Building, Nottingham. e-mail. margarita.rubio@nottingham.ac.uk.

${ }^{\dagger}$ University of Portsmouth, Portland St, Portsmouth PO1 3DE, UK. E-mail: jose.carrasco-gallego@port.ac.uk. This paper was presented in the Macroeconomics Poster Session at the ASSA Meetings 2014 (Philadelphia, January 3rd, 2014). It was also presented at the RES 2014, Encuentro de Economia Aplicada 2014, and the 7th CGBCR Conference at the University of Manchester. The authors wish to thank Matteo Iacoviello, Rafael Repullo, Guido Ascari, George Bratsiotis, and three anonymous referees for their very useful comments. We are responsible for all errors.
} 
" The financial crisis brought home the lesson that financial stability could not be assured only through the use of microprudential tools. And so Basel III represents another important step in the Committee's development. Basel III has substantially enhanced the microprudential framework. And, in the countercyclical buffer, it has also introduced the first international agreement on a macroprudential tool". Stefan Ingves, Chairman of the Basel Committee on Banking Supervision and Governor of Sveriges Riksbank, at a symposium to mark 25 years of the Basel Capital Accord: 25 years of international financial regulation: Challenges and opportunities, Basel, 26 September 2013.

\section{Introduction}

After the introduction of new bank capital regulations by the Basel accords, there exists a continuing public policy concern about the macroeconomic impact of these codes of practice, especially in the aftermath of the financial crisis. In this paper, we perform an analysis of the impact of fixed capital requirements corresponding to Basel I, II, and III in a DSGE model featuring a housing market and a financial intermediary. ${ }^{1}$ We contribute to the literature on several fronts. First, we explore the distributional implications of bank capital requirements imposed by Basel I, II, and III on patient unconstrained savers, impatient financial constrained borrowers, and financial intermediaries. While the literature finds a small aggregate impact, our results show larger distributional effects: savers are better off when banks are required to hold more capital, but borrowers and banks are initially worse off with this measure. Second, we are able to quantify the gains in financial stability coming from the regulation, by taking the variability of borrowing as the closest measure. ${ }^{2}$ Third, we propose a rule to approximate the countercyclical capital buffer in which the capital requirement responds not only to credit variables but also to house prices and output. Finally, we contribute to the discussion of the procyclical effects of Basel III by showing that, for the optimal implementation that we calculate, the regulation is countercyclical for borrowers and banks while procyclical for savers.

In order to achieve our research goals, we build a dynamic stochastic general equilibrium model (DSGE). The advantage of using this kind of models is that, since they are general equilibrium, they can account for the interactions of all the relevant variables in the economy. They are dynamic, and therefore the effects of different shocks can be studied. They rely on deep parameters and are, thus,

\footnotetext{
${ }^{1}$ The machinery of this paper cannot compare Basel I with Basel II since this would require distinguishing two assets of different riskiness in order to introduce the impact of Basel II risk weightings based on the internal ratings-based (IRB) risk curves, and, in this model, there is only one kind of bank lending. Then, Basel I and Basel II are analyzed together.

${ }^{2}$ Note that in a linearized model it is difficult to find a definition for financial stability.
} 
free from the Lucas critique, allowing to analyze counterfactuals and do policy evaluation. And finally, since they are microfounded, they are suitable for welfare analysis. In particular, we construct a Real Business Cycle model (RBC) which relies on technology shocks as the main source of macroeconomic fluctuations. ${ }^{3}$

Our model features borrowers, savers, and financial intermediaries. The reason for splitting households into borrowers and savers is that in this way, in equilibrium, credit is not zero as in a representative agent problem. Borrowers are constrained in the amount they can borrow while banks are constrained in the amount they can lend; that is, they have a capital requirement ratio. We study first how capital requirements affect dynamics and welfare. We observe that higher capital requirements decrease the quantity of borrowing in the economy and that reduces borrowers and banks consumption. In terms of welfare, savers are better off if capital requirements increase, while borrowers and banks are worse off initially. After a certain threshold, volatility effects prevail for these latter agents and their welfare also increases.

Then, we propose a macroprudential rule for the capital buffer of Basel III. Authorities may emphasize any variables that make sense to them for purposes of assessing the sustainability of credit growth and the level of system-wide risk. Some examples of variables that may be useful indicators are asset prices, GDP, and credit condition indicators. Then, along these lines, we propose a countercyclical macroprudential rule in which capital requirements respond to credit growth, output and housing prices. Then, we compute the optimal parameters that maximize welfare. Our results show that the regulator, when implementing the rule, should attach relatively more weight to output and house prices, rather than to credit growth, given that the former ones serve as an anticipated indicator of credit growth; when the regulator observes credit growth itself, it may be too late to avoid it. An optimal implementation of the macroprudential component of Basel III is welfare improving. Furthermore, the optimal implementation of Basel III with the countercyclical capital buffer is, precisely, countercyclical for banks and borrowers, the ones directly affected by capital requirements and collateral constraints, but procyclical for savers, not affected by any friction.

The rest of the paper continues as follows. Section 1.1 makes a review of the literature. Section 2 presents the modeling framework. Section 3 displays simulations. Section 4 studies welfare. Section 5 analyzes the optimal implementation of the countercyclical capital buffer of Basel III. Section 6 concludes.

\footnotetext{
${ }^{3}$ Since this paper does not focus on monetary policy, prices are fully flexible here.
} 


\subsection{Policy Background and Related Literature}

Basel III is a comprehensive set of post-crisis reform measures in banking regulation, supervision and risk management. It was developed by the Basel Committee on Banking Supervision (BCBS) at the Bank for International Settlements (BIS), to strengthen the banking sector and achieve financial stability. Furthermore, some of the new measures that Basel III introduces are aimed at preventing future crises, creating a sound financial system in which financial problems are not spread to the real economy. Preventive measures acting in this direction are known between researchers and policy-makers as "macroprudential policies."

The BCBS seeks to deliver some guidance for banking regulators on what the best practice for banks is. Its standards are accepted worldwide and are generally incorporated in national banking regulations. Basel I, signed in 1988, was the first accord on the issue. Basel I primarily focused on credit risk: banks with international presence were required to hold capital equal to $8 \%$ of the risk-weighted assets. Basel II, initially published in June 2004, was intended to create an international standard for banking regulators to control how much capital banks need to put aside to guard against the types of financial and operational risks banks and the whole economy face. The BCBS issued a new agreement in 2010, known as the Basel III Accord, to increase the resilience of the system and to prevent the occurrence of a financial crisis in the future. This new accord introduces a mandatory capital conservation buffer of $2.5 \%$ designed to enforce corrective action when a bank's capital ratio deteriorates. Then, although the minimum total capital requirement remains at the current $8 \%$ level, yet the required total capital increases up to $10.5 \%$ when combined with the conservation buffer. Furthermore, it also adds a macroprudential element in the form of a countercyclical capital buffer up to another $2.5 \%$ of capital, which asks banks to hold more capital in good times to prepare for inevitable downturns in the economy. In this way, Basel III tries to achieve the broader macroprudential goal of reducing systemic risk, which in turns protects the banking sector from periods of excessive credit growth.

Our work is related with the literature which emphasizes the externalities associated with bank lending and credit and in particular through the price of collateral. For instance, Lorenzoni (2008) and Bianchi (2011) highlight that when individual financial institutions borrow, they may not take into account the possibility that their action could depress collateral values and hence tighten the borrowing constraints throughout the system. In this spirit, the macroprudential tool that we propose for the countercyclical capital buffer of Basel III can maintain financial stability by explicitly accounting for the 
externalities arising from the behavior of individual institutions as well as the structure of the financial system. This tool may face the ex-ante externalities that lead to an excessive build-up of systemic risk, and the ex-post externalities that can generate inefficient failures of institutions in a crisis. As well, Aikman et al. (2010) and Aikman et al. (2012) consider that banks may have incentives to undertake excessive lending due to strategic complementarities (reputational concerns, for instance) when other banks are profitable and are expanding lending. Therefore, an increase in our countercyclical capital buffer during a credit boom would improve resilience directly by enhancing the loss-absorbing capacity of the system because it would tighten the constraint on financial institutions, such that they cannot increase their risk-weighted assets beyond a certain multiple of equity capital. This policy action could in some circumstances, as Giese et al. (2013) describe, raise the funding costs of financial institutions. When higher funding costs translate into higher lending rates, credit growth would slow down. In addition to increasing banks' capacity to absorb losses, stricter capital requirements might therefore help moderate an unsustainable credit boom, thereby reducing the probability of a crisis

The seminal contribution by Kiyotaki and Moore (1997) stress that collateralized borrowing hinges on market values, yet such market values are endogenous to the economy and out of control by creditors and debtors. In that line of research, the recent work of Pintus et al. (2015) point out that the market value of collateral generates an externality that serves to amplify and propagate business cycle shocks. We find that this externality can be used in a countercyclical way for macroprudential purposes. That is, we use this externality to control the cycle via a macroprudential tool based on the price of collateral. For instance, when the economy is overheated, the macroprudential tool can let the market value of collateral to be below trend, collateralized borrowing restricts credit lending, and, thanks to the externality, this creates a downturn.

Our paper is also connected as well with the literature that uses a DSGE model to study the effects of a macroprudential rule, given the macroprudential flavor of Basel III. For instance, Antipa et al. (2010) use a DSGE model to show that macroprudential policies would have been effective in smoothing the past credit cycle and in reducing the intensity of the recession. Some of the scholars have used this type of models to study the loan-to-value ratio (LTV) as a macroprudential tool, such as Kannan et al. (2012) or Rubio and Carrasco-Gallego (2015), among others. In our paper, we also use a DSGE framework to evaluate the capital requirement ratios of Basel I and II (8\%) and Basel III (10.5\%) plus the optimal parameterization of the countercyclical capital buffer as a macroprudential tool. Our strategy can be summarized as consistent on adding a second layer of financially constrained agents which are the banks. 
We use this framework to evaluate the compulsory capital requirement ratios of Basel I, II and III and the countercyclical capital buffer that this latter regulation proposes.

This setting lets us add some light to the discussion about capital regulation that the recent financial crisis put at the forefront. Even the BCBS recognizes a negative but low effect on economic growth although considers that the benefits from reducing the probability of financial crises and the output losses associated with such crises are larger (see BCBS, 2010). In this line, some policy-makers and scholars argue in favour of a substantial increase in capital requirements (see, e.g., Admati et al., 2013) because of the positive welfare effects. Albeit, others claim that a more restrictive bank regulation might have negative impact for credit extension and growth (see, e.g., Adrian and Ashcraft, 2012). The welfare evaluation that we develop is a complete welfare analysis for the different agents of the economy that lets a better understanding of a change in the capital requirement ratio because it disentangles the level and volatility effects for each agent. We find that the distributional impacts are relatively large, even when the aggregate welfare effects are small, because there is a welfare trade-off between borrowers and savers.

We also contribute by proposing a macroprudential rule for the capital buffer of Basel III. Before us, other academics have analyzed this capital buffer with a DSGE framework and proposed some rules. For instance, Kannan et al. (2012) assume that policy-makers can affect the market lending rate by imposing additional capital requirements or additional provisioning when credit growth is above its steady-state value. Angelini et al. (2014) introduce a time-varying capital ratio that adjusts the requirements only in response to movements in the loans-to-output ratio. We propose a macroprudential rule for the capital buffer of Basel III in which capital requirements respond to credit growth, output and house prices. We believe that these three variables are able to capture the spirit of BCBS (2010) that considers that useful indicators of assessing the sustainability of credit growth and the level of system-wide risk are asset prices, GDP, and credit condition indicators. Drehmann et al. (2010) also point out that the deviations of credit from its long-term trend are very good indicators of the increase in systemic risk, which is the macroprudential attention. We find the optimal parameters of the rule that maximize welfare and see that the regulator should attach relatively more weight to the output and the house price parameters in the rule, rather than to the credit growth parameter, given that they serve as an anticipated indicator of credit growth. Our results are in line of Jiménez et al.(2014) who empirically show that building up capital buffers before a crisis occurs is superior in terms of maintaining real activity and avoiding risk-shifting than changing requirements during the crisis period. In terms of welfare, we see that the 
macroprudential component of Basel III delivers higher welfare for the society than a situation with no regulation.

With this paper, we add some new insights to the analysis of the cyclicality of the new regulation. Our model dynamics show that, using the optimized parameters for the macroprudential capital buffer, after an expansionary shock, when GDP is going up, the regulator increases capital requirements. This, in turn, cuts borrowing, and achieves the goal of the regulation, which is to avoid excessive credit growth. A number of other studies have also found that increasing capital requirements may reduce credit supply (Kishan and Opiela, 2000; Gambacorta and Mistrulli, 2004). In the same line, Akram (2014) finds that the proposed increases in capital requirements under Basel III are found to have significant effects especially on house prices and credit. Our results are related to Drehmann and Gambacorta (2011) which show a simulation that indicates that the countercyclical buffer scheme might reduce credit growth during credit booms and decrease the credit contraction once the buffer is released. This would help to achieve higher banking sector resilience to shocks. Nevertheless, their procedure is subject to the Lucas critique: had the scheme been in place, banks' lending decisions would probably have been different. However, our approach is robust to this critique because is based on a DSGE model.

There also exists some controversy around this regulation that has been pointed out by the literature. In particular, some concerns have been raised about the impact of Basel III reforms on the dynamism of financial markets and, in turn, on investment and economic growth. The reasoning is that Basel III regulation could produce a decline in the amount of credit and impact negatively in the whole economy. Critics of Basel III consider that there is a real danger that this reform will limit the availability of credit and reduce economic activity. Repullo and Saurina (2012) show that a mechanical application of Basel III regulation would tend to reduce capital requirements when GDP growth is high and increase them when GDP growth is low. Then, if banks increase capital requirements during crises, credit will be reduced and the economic growth will be even lower; with a lower growth, welfare will decrease. This is the so-called risk of procyclicality, that is, Basel III could cause a deeper recession in bad times and a higher boom in good ones. Furthermore, it could have an adverse impact on growth plans of the industry, as pointed out by Kant and Jain (2013). If capital requirement ratios increase, households and industries cannot borrow as much, and their plans for recovery would be affected, having an impact on the whole economy. Some authors have attempted to evaluate the effects of capital ratios such as Angeloni and Faia (2013) and Repullo and Suárez (2013). They compare the procyclicality of Basel II and Basel I, the previous frameworks. They find that Basel II is more procyclical than Basel I. In our 
paper, we add to this discussion. Our results show that the effect is countercyclical for borrowers and banks, the agents directly affected by capital requirements, while procyclical for savers.

\section{Model Setup}

The economy features patient and impatient households, banks and a final goods firm. Households work and consume both consumption goods and housing. Patient and impatient households are savers and borrowers, respectively. Financial intermediaries intermediate funds between consumers. Banks are credit constrained in how much they can borrow from savers, and borrowers are credit constrained with respect to how much they can borrow from banks. The representative firm converts household labor into the final good.

\subsection{Savers}

Savers maximize their utility function by choosing consumption, housing and labor hours:

$$
\max E_{0} \sum_{t=0}^{\infty} \beta_{s}^{t}\left[\log C_{s, t}+j \log H_{s, t}-\frac{\left(N_{s, t}\right)^{\eta}}{\eta}\right],
$$

where $\beta_{s} \in(0,1)$ is the patient discount factor, $E_{0}$ is the expectation operator and $C_{s, t}, H_{s, t}$ and $N_{s, t}$ represent consumption at time t, the housing stock and working hours, respectively. $1 /(\eta-1)$ is the labor supply elasticity, $\eta>0 . j>0$ constitutes the relative weight of housing in the utility function. Subject to the budget constraint:

$$
C_{s, t}+D_{t}+q_{t}\left(H_{s, t}-H_{s, t-1}\right)=R_{s, t-1} D_{t-1}+W_{s, t} N_{s, t}
$$

where $D_{t}$ denotes bank deposits, $R_{s, t}$ is the gross return from deposits, $q_{t}$ is the price of housing in units of consumption, and $W_{s, t}$ is the wage rate. The first order conditions for this optimization problem are as follows:

$$
\begin{gathered}
\frac{1}{C_{s, t}}=\beta_{s} E_{t}\left(\frac{1}{C_{s, t+1}} R_{s, t}\right) \\
\frac{q_{t}}{C_{s, t}}=\frac{j}{H_{s, t}}+\beta_{s} E_{t}\left(\frac{q_{t+1}}{C_{s, t+1}}\right) \\
W_{s, t}=\left(N_{s, t}\right)^{\eta}-1 C_{s, t}
\end{gathered}
$$


Equation (2) is the Euler equation, the intertemporal condition for consumption, which implies that savers smooth consumption over time. Equation (3) represents the intertemporal condition for housing, in which, at the margin, benefits for consuming housing equate costs in terms of consumption. Equation (4) is the labor-supply condition.

\subsection{Borrowers}

Borrowers solve:

$$
\max E_{0} \sum_{t=0}^{\infty} \beta_{b}^{t}\left[\log C_{b, t}+j \log H_{b, t}-\frac{\left(N_{b, t}\right)^{\eta}}{\eta}\right]
$$

where $\beta_{b} \in(0,1)$ is the impatient discount factor, subject to the budget constraint and the collateral constraint: ${ }^{4}$

$$
\begin{gathered}
C_{b, t}+R_{b, t} B_{t-1}+q_{t}\left(H_{b, t}-H_{b, t-1}\right)=B_{t}+W_{b, t} N_{b, t}, \\
B_{t} \leq E_{t}\left(\frac{1}{R_{b, t+1}} k q_{t+1} H_{b, t}\right)
\end{gathered}
$$

where $B_{t}$ denotes bank loans and $R_{b, t}$ is the gross interest rate to be paid by borrowers for their loans. $k$ can be interpreted as a loan-to-value ratio. ${ }^{5}$ The borrowing constraint limits borrowing to the present discounted value of their housing holdings, that is, they use housing as collateral. ${ }^{6}$ The first order conditions are as follows:

$$
\begin{gathered}
\frac{1}{C_{b, t}}=\beta_{b} E_{t}\left(\frac{1}{C_{b, t+1}} R_{b, t+1}\right)+\lambda_{b, t}, \\
\frac{j}{H_{b, t}}=E_{t}\left(\frac{1}{C_{b, t}} q_{t}-\beta_{b} E_{t}\left(\frac{q_{t+1}}{C_{b, t+1}}\right)\right)-\lambda_{b, t} \frac{1}{R_{b, t+1}} k q_{t+1},
\end{gathered}
$$

\footnotetext{
${ }^{4}$ Our setup is DSGE, since it represents an extension of a simple Real Business Cycle (RBC) model with collateral constraints a-la-Kiyotaki and Moore. The stochastic nature of the model comes from technology shocks, which are the source of business cycle fluctuations. As in Kiyotaki and Moore (1997), the introduction of the collateral constraint ensures that debt repayments are always fulfilled and default is ruled out.

${ }^{5}$ Rubio and Carrasco-Gallego (2014) find that, starting from a value of the LTV of 0.55, there is a trade-off between borrowers and savers in terms of welfare when we keep increasing the LTV. Large values of the LTV harm borrowers while savers benefit from the increase. Social welfare decreases.

${ }^{6}$ This collateral constraint a-la-Kiyotaki and Moore generates a financial accelerator. Shocks that lower house prices make consumption by borrowers decrease through the loan-to-value constraint, in the spirit of what happened during the recent financial crisis.
} 


$$
W_{b, t}=\left(N_{b, t}\right)^{\eta}-1 C_{b, t},
$$

where $\lambda_{b, t}$ denotes the multiplier on the borrowing constraint. These first order conditions can be interpreted analogously to the ones of savers with the difference that collateral terms appear in them reflecting wealth effects. Through simple algebra, it can be shown that the Lagrange multiplier is positive in the steady state and thus the collateral constraint holds with equality. ${ }^{7}$ This means that borrowers, unlike savers, cannot smooth consumption because their consumption comes determined by how much they can borrow. ${ }^{8}$ This represents the first distortion of the model: borrowers do not have free access to financial markets and thus cannot freely smooth consumption.

\subsection{Financial Intermediaries}

Banks solve the following problem:

$$
\max E_{0} \sum_{t=0}^{\infty} \beta_{f}^{t}\left[\log D i v_{f, t}\right],
$$

where $\beta_{f} \in(0,1)$ is the financial intermediary discount factor and $D i v_{f, t}$ are dividends. Subject to the budget constraint and the collateral constraint: ${ }^{9}$

$$
\operatorname{Div}_{f, t}+R_{s, t-1} D_{t-1}+B_{t}=D_{t}+R_{b, t} B_{t-1}
$$

where the right-hand side measures the sources of funds for the financial intermediary; household deposits and repayments from borrowers on previous loans. The funds can be used to pay back depositors and to extend new loans, or can be used as dividends. We assume here that dividends are transformed into consumption by banks, so that $\operatorname{Div}_{f, t}=C_{f, t}$. As in Iacoviello (2015), we assume that the bank, by regulation, is constrained by the amount of assets minus liabilities, as a fraction of assets. That is, there is a capital requirement ratio. We define capital as assets minus liabilities, so that, the fraction of capital with respect to assets has to be larger than a certain ratio:

\footnotetext{
${ }^{7}$ In this model, as in Iacoviello-type models, low uncertainty and small curvature of the utility function are sufficient to guarantee that the borrowing constraint is always binding over the relevant range and therefore there is no negative consumption.

${ }^{8}$ As discussed in Iacoviello (2005), the frequency of borrowing constrained periods depends on the loan-to-value ratio.

${ }^{9}$ In a model without banks and a capital constraint, there would not be any spread between the lending and the deposit rate. The capital constraint is introducing an extra distortion in the economy that affects agents' welfare.
} 


$$
\frac{B_{t}-D_{t}}{B_{t}} \geq C R R
$$

Simple algebra shows that this relationship can be rewritten as:

$$
D_{t} \leq(1-C R R) B_{t}
$$

If we define $\gamma=(1-C R R)$, we can reinterpret the capital requirement ratio condition as a standard collateral constraint, so that banks liabilities cannot exceed a fraction of its assets, which can be used as collateral: ${ }^{10}$

$$
D_{t} \leq \gamma B_{t}
$$

where $\gamma<1$. The first order conditions for deposits and loans are as follows:

$$
\begin{gathered}
\frac{1}{C_{f, t}}=\beta_{f} E_{t}\left(\frac{1}{C_{f, t+1}} R_{s, t}\right)+\lambda_{f, t}, \\
\frac{1}{C_{f, t}}=\beta_{f} E_{t}\left(\frac{1}{C_{f, t+1}} R_{e, t+1}\right)+\gamma \lambda_{f, t},
\end{gathered}
$$

where $\lambda_{f, t}$ denotes the multiplier on the financial intermediary's borrowing constraint. Financial intermediaries have a discount factor $\beta_{f}<\beta_{s}$. This condition ensures that the collateral constraint of the intermediary holds with equality in the steady state, since $\lambda_{f}=\frac{\beta_{s}-\beta_{f}}{\beta_{s}}>0 .{ }^{11}$ This binding constraint represents the second distortion of the model. The fact that financial intermediaries need to hold a certain amount of capital determines their dividends and therefore their consumption. Thus, like borrowers, they are not consumption smoothers. ${ }^{12}$

Table 1 displays the assets and the liabilities of the different agents for a better understanding of the

\footnotetext{
${ }^{10}$ This constraint creates a relationship between capital requirements and the volatility of borrower consumption. Bank capital constraints provide a substantial benefit of reducing the sensitivity of consumption to house prices and avoiding financial problems.

${ }^{11}$ In the real world, bank capital reduces moral hazard problems and the probability of a financial crisis. However, the model is not able to capture such benefits due to the presence of binding borrowing constraints that rule out the possibility of firms and banks to go in default. However, as Clerc et al. (2014) find, using a DSGE model, the probability of default for banks is negligible for capital requirement ratios higher than $10 \%$, in the range of Basel III regulation.

${ }^{12}$ The model without banks reduces to Iacoviello (2005) or Rubio and Carrasco-Gallego (2014). These models are similar in spirit to this one but display a collateral constraint only on the borrower's side. In these models, the binding loanto-value constraint is essential in order for the economy to be endogenously divided into borrowers and savers, so that it is assured that borrowers always borrow and consume a positive amount, which is financed by the savers. At the same time, the model dynamics are symmetric under the assumption of different discount factors among agents, which makes the constraint always binding, provided that shocks are small enough. As in Iacoviello (2005), this is the approach we take.
} 
structure of the model.

\begin{tabular}{|c|c|c|c|c|c|c|}
\hline \multicolumn{7}{|c|}{ Table 1: Assets and Liabilities } \\
\hline \hline & \multicolumn{2}{|c|}{ Savers } & \multicolumn{2}{c|}{ Borrowers } & \multicolumn{2}{c|}{ Banks } \\
\hline \hline & Assets & Liabilities & Assets & Liabilities & Assets & Liabilities \\
\hline Deposits & $D_{t}$ & & & & & $D_{t}$ \\
\hline Borrowing & & & & $B_{t}$ & $B_{t}$ & \\
\hline Housing & $q_{t} H_{s, t}$ & & $q_{t} H_{b, t}$ & & & \\
\hline Equity Capital & & & & & & $(1-\gamma) B_{t}$ \\
\hline
\end{tabular}

\subsection{Firms}

Firms produce the final consumption good. The problem for the final good firms is standard and static. They maximize profits subject to the production function by using labor from both types of households: ${ }^{13}$

$$
\begin{gathered}
\max \Pi_{t}=Y_{t}-W_{s, t} N_{s, t}-W_{b, t} N_{b, t} \\
Y_{t}=A_{t} N_{s, t}^{\alpha} N_{b, t}^{1-\alpha}
\end{gathered}
$$

where $A_{t}$ represents a technology parameter. The problem delivers the standard first-order conditions, which represent the labor-demand equations:

$$
\begin{gathered}
W_{s, t}=\frac{\alpha Y_{t}}{N_{s, t}}, \\
W_{b, t}=\frac{(1-\alpha) Y_{t}}{N_{b, t}} .
\end{gathered}
$$

\subsection{Equilibrium}

The total supply of housing is fixed and it is normalized to unity:

$$
H_{s, t}+H_{b, t}=1 \text {. }
$$

\footnotetext{
${ }^{13}$ Following the literature that starts with Kiyotaki and Moore (1997) and builds up with Iacoviello (2005) and Iacoviello (2015), we assume that output is produced with labor supplied from both agents. In this way we make our model comparable with the rest of the literature.
} 
The goods market clearing condition is as follows:

$$
Y_{t}=C_{s, t}+C_{b, t}+C_{f, t}
$$

Labor supply (equations 4 and 9) and labor demand (equations 17 and 18) are equal to each other, so that labor markets also clear. Equilibrium in financial markets is dictated by the regulatory constraint for banks, that is, $D_{t}=(1-C R R) B_{t}$.

\section{Simulation}

\subsection{Parameter Values}

The discount factor for savers, $\beta_{s}$, is set to 0.99 so that the annual interest rate is $4 \%$ in steady state. The discount factor for the borrowers is set to 0.98. ${ }^{14}$ As in Iacoviello (2015), we set the discount factors for the bankers at 0.965 which, together with the bank leverage parameters implies a spread of about 1 percent (on an annualized basis) between lending and deposit rates. The steady-state weight of housing in the utility function, $j$, is set to 0.1 in order for the ratio of housing wealth to GDP to be approximately 1.40 in the steady state, consistent with the US data. We set $\eta=2$, implying a value of the labor supply elasticity of $1 .{ }^{15}$ For the parameters controlling leverage, we set $k$ and $\gamma$ to 0.90 , which implies a capital requirement ratio of $10 \%$, in line with the US data. ${ }^{16}$ The labor income share for savers is set to 0.64 , following the estimate in Iacoviello (2005). We assume that technology, $A_{t}$, follows an autoregressive process with 0.9 persistence and a normally distributed shock. Table 2 presents a summary of the parameter values used:

\footnotetext{
${ }^{14}$ Lawrance (1991) estimated discount factors for poor consumers at between 0.95 and 0.98 at quarterly frequency. We take the most conservative value.

${ }^{15}$ Microeconomic estimates usually suggest values in the range of 0 and 0.5 (for males). Domeij and Flodén (2006) show that in the presence of borrowing constraints this estimates could have a downward bias of $50 \%$.

${ }^{16}$ See Iacoviello (2015).
} 


\begin{tabular}{|c|c|c|}
\hline \multicolumn{2}{|c|}{ Table 2: Parameter Values } \\
\hline \hline$\beta_{s}$ & .99 & Discount Factor for Savers \\
\hline$\beta_{b}$ & .98 & Discount Factor for Borrowers \\
\hline$\beta_{f}$ & .965 & Discount Factor for Banks \\
\hline$j$ & .1 & Weight of Housing in Utility Function \\
\hline$\eta$ & 2 & Parameter associated with labor elasticity \\
\hline$k$ & .90 & Loan-to-value ratio \\
\hline$C R R$ & .10 & Capital Requirement ratio \\
\hline$\alpha$ & .64 & Labor income share for Savers \\
\hline$\rho_{A}$ & .9 & Technology persistence \\
\hline
\end{tabular}

\subsection{Dynamics}

\subsubsection{Baseline Model}

In this section, we simulate the impulse responses of the baseline model to illustrate its dynamics. ${ }^{17}$

Figure 1 presents the impulse responses to a 1 percent shock to technology. ${ }^{18}$ Notice that this represents a positive analysis in which the dynamics of the model are described. Given the increase in technology, output increases and thus, consumption for the three agents increases. Borrowing increases and borrowers demand more housing, which is just partially compensated by a decrease in the housing by the savers. The increase housing demand, makes house prices go up. Therefore, since now housing collateral is worth more, consumption for borrowers increases further, given the collateral constraint they face. In this model, wealth effects are present through the collateral constraint. Situations in which house prices increase make the value of the collateral higher, and thus, wealth effects expand the economy even further. ${ }^{19}$

\footnotetext{
${ }^{17}$ We solve the model using the standard approach in the literature that is, linearizing the structural equations around the deterministic steady state. A DSGE model takes the mathematical form of a system of nonlinear stochastic equations. Except in a very few cases, there is no analytical solution and we need to obtain approximated solutions. Global approximation methods are available when the state space is not too large, while the most usual approach is local approximation around the deterministic steady state. The deterministic steady state, as we use for our solution, is defined as the equilibrium position of the system in absence of shocks: it is the point in the state space where agents decide to stay when there is no shock in the current period and they do not expect any shocks in the future. One of the shortcomings of this approach is that the deterministic steady state ignores agents' attitude towards risk, because uncertainty is removed from the deterministic version of the model.

${ }^{18}$ Given the collateral constraints introduced in this model, it displays a financial accelerator. This means that even though shocks are generated in the real sector, they will be transmitted and amplified through the financial sector. In this way, TFP shocks are reflecting the interconnectedness between the real economy and financial markets and therefore can be a good source of disturbances to evaluate the regulation.

${ }^{19}$ Simulations to positive and negative shocks are symmetric.
} 

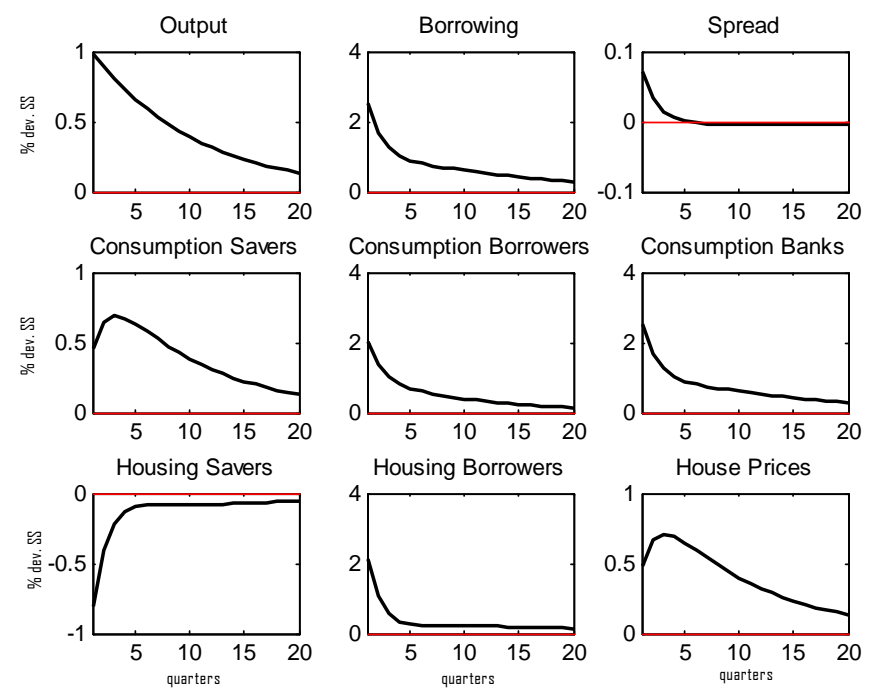

Figure 1: Impulse responses to a technology shock.

\subsubsection{Different Capital Requirements}

In order to understand the effect of the regulation on banks on the dynamics, here we simulate the model for different capital requirement ratios.

Figure 2 presents impulse responses to a technology shock for three different capital requirement ratios. We observe that, when the capital requirement ratio increases, borrowing decreases, the interest rate spread increases, and therefore borrowers consume less. Banks, since they are not able to lend as much, also suffer a decrease in their consumption. However, the effect is the opposite for savers and this compensates the effect on borrowers and banks. Therefore, the overall effects are distributional and they do not affect the aggregate. Notice that these are, though, first order level effects and, while describing the dynamics of the model, represent positive results. In order to infer some normative conclusion, a welfare analysis must be made. We perform this exercise in the following section.

\section{Welfare}

\subsection{Welfare Measure}

To assess the normative implications of the different policies, we numerically evaluate the welfare derived in each case. As discussed in Benigno and Woodford (2008), a popular approach that has recently been used for welfare analysis in DSGE models include solving the model using a second-order approximation 

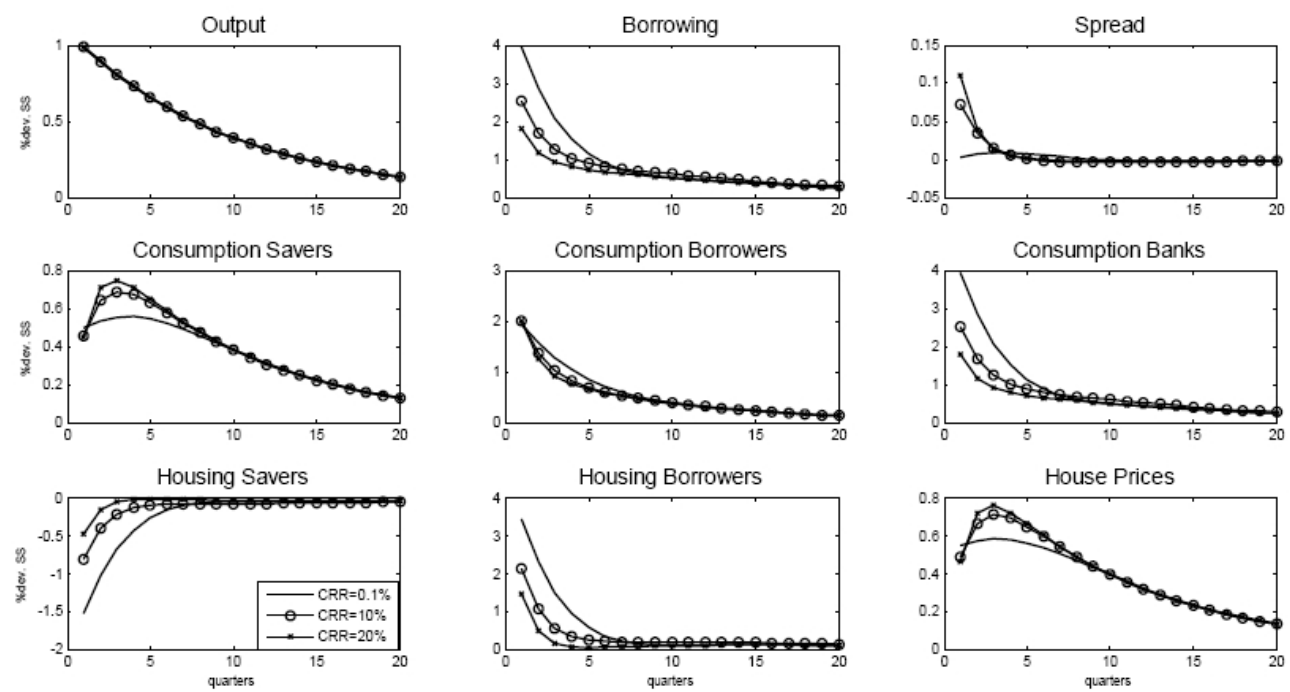

Figure 2: Impulse responses to a technology shock. Different capital requirement ratios.

to the structural equations for given policy and then evaluating welfare using this solution. Thus, we have used the software Dynare to obtain a solution for the equilibrium implied by a given policy by solving a second-order approximation to the constraints, then evaluating welfare under the policy using this approximate solution, as in Schmitt-Grohe and Uribe (2004). ${ }^{20}$ In particular, we evaluate the welfare of the three types of agents separately. The individual welfare for savers, borrowers, and the financial intermediary, respectively, is as follows:

$$
\begin{gathered}
W_{s, t} \equiv E_{t} \sum_{m=0}^{\infty} \beta_{s}^{m}\left[\log C_{s, t+m}+j \log H_{s, t+m}-\frac{\left(N_{s, t+m}\right)^{\eta}}{\eta}\right] \\
W_{b, t} \equiv E_{t} \sum_{m=0}^{\infty} \beta_{b}^{m}\left[\log C_{b, t+m}+j \log H_{b, t+m}-\frac{\left(N_{b, t+m}\right)^{\eta}}{\eta}\right] \\
W_{f, t} \equiv E_{t} \sum_{m=0}^{\infty} \beta_{f}^{m}\left[\log C_{f, t+m}\right]
\end{gathered}
$$

Following Mendicino and Pescatori (2007), we define social welfare as a weighted sum of the individual welfare for the different types of households:

\footnotetext{
${ }^{20}$ This approach has become popular in the literature. See for instance, Faia and Monacelli (2007), Bergin et al (2007), Kim and Ruge-Murcia (2009).
} 


$$
W_{t}=\left(1-\beta_{s}\right) W_{s, t}+\left(1-\beta_{b}\right) W_{b, t}+\left(1-\beta_{f}\right) W_{f, t} .
$$

Each agent's welfare is weighted by her discount factor, respectively, so that the all the groups receive the same level of utility from a constant consumption stream.

\subsection{Capital Requirement Ratios}

Figure 3 displays the welfare that each group obtains when increasing the capital requirement ratio for banks. Notice that results are presented in welfare units (utils), ${ }^{21}$ since the purpose of this figure is to illustrate the issue from an ordinal point of view. ${ }^{22}$ On the other hand, Table 3 presents a measure for financial stability associated with different capital requirements. We take the standard deviation of credit as a proxy for financial stability, since a stable financial system is one in which variability of credit is low.

Remember that there are two distortions in this economy, corresponding to the two collateral constraints, the one for the borrowers and the one for the financial intermediaries, respectively. Capital requirements affect directly the second distortion. Savers do not suffer from any of the distortions. ${ }^{23}$ We see that there is a welfare trade-off between borrowers and savers. While savers are better off when banks are required to hold more capital, borrowers are initially worse off with this measure. For the range of values analyzed, savers are always better off than in a situation with no regulation. Borrowers are worse off for initial increases but their welfare starts to recover for capital requirements greater than $6 \%$. For capital requirements in the range of $6-16 \%$, they are still worse off than initially. Nevertheless, for capital requirements larger than $16 \%$, they are better off than in a situation with no regulation. The reason is that, initially, increasing the capital requirement does not allow borrowers borrow as much as they would like, the interest rate spread increases, and therefore their consumption decreases. This is the level effect that affects them negatively. However, as we can see in Table 3, a higher financial stability is achieved the higher capital requirements are, and this fact has an effect in terms of consumption stability. For larger values of the capital requirement ratio, even though the level of consumption decreases, the

\footnotetext{
21 "Utils" refer to the units of welfare in a utility scale. Therefore, the change in utils measures, from an ordinal point of view, whether agents are better off.

${ }^{22}$ In this section and the next one, we do not consider welfare in consumption equivalent units since it is not clear what the benchmark situation would be. However, in subsequent sections, when we make the comparison between Basel I, II with Basel III, we take the first case as a benchmark and present welfare gains from the new regulation in consumption equivalents.

${ }^{23}$ Note that in a model with sticky prices, this distortion would affect savers. Prices are fully flexible in this setting.
} 
volatility effect prevails and this is why borrowers end up being better off. Saving is equal to borrowing in equilibrium. Thus, since the level of borrowing decreases with higher capital requirements, savers can use part of their saving for their own consumption. Therefore, savers are better off.

For banks, the argument is similar to the one of the borrowers. Albeit their welfare decreases for lower values of the capital requirement ratio, it starts to increase from a certain value of this parameter. When capital requirements increase, banks cannot lend as much as they would like and their constraint becomes tighter. This negatively affects their dividend as a level effect. Nevertheless, welfare values increase after a certain threshold of the capital requirement ratio. Thus, for lower values of the capital requirement ratio, below the range of the Basel regulation, banks welfare slightly decreases. However, increasing the capital requirement ratio further helps reducing the distortion implied by the collateral constraint of bankers. Given that they cannot smooth their consumption by themselves, higher capital requirements limit the loans they can make, stabilizing the financial system and, therefore, making their pattern of consumption also more stable. This is the volatility effect implied by a more stable financial system, as shown in Table 3.

The lower left panel represents welfare of the households, disregarding banks. If we look at the welfare of the households, we see that increasing capital requirements is welfare enhancing, ${ }^{24}$ that is, the welfare gain experimented by the savers compensates the initial loss of the borrowers. ${ }^{25}$

\begin{tabular}{lccccc}
\hline \hline \multicolumn{6}{l}{ Table 3: Volatility of Borrowing } \\
\hline \hline CRR & $\mathbf{1 \%}$ & $\mathbf{5 \%}$ & $\mathbf{1 0 \%}$ & $\mathbf{1 5 \%}$ & $\mathbf{2 0 \%}$ \\
\hline STD (B) & 5.97 & 4.98 & 4.17 & 3.60 & 3.17 \\
\hline
\end{tabular}

\section{Optimal Implementation of Basel III}

Basel III states that there should be an extra countercyclical capital buffer in order to avoid excessive credit growth. The purpose of this buffer is the protection of the whole banking system from periods of excessive credit growth activities. It will work on preventing banks from following more than needed expansionary credit policies during economic booms that would increase the severity of inflation or more than needed contractionary ones during deflation that would deepen the economic downturn.

The size of the buffer is set by the regulator and must take into account the macroeconomic environment in which banks operate. Therefore, it will be applied considering national circumstances of

\footnotetext{
${ }^{24}$ Higher capital requirements increase borrower welfare in steady state. The effects in transition may be different.

${ }^{25}$ The "Households" panel corresponds to the aggregation between borrowers and savers.
} 

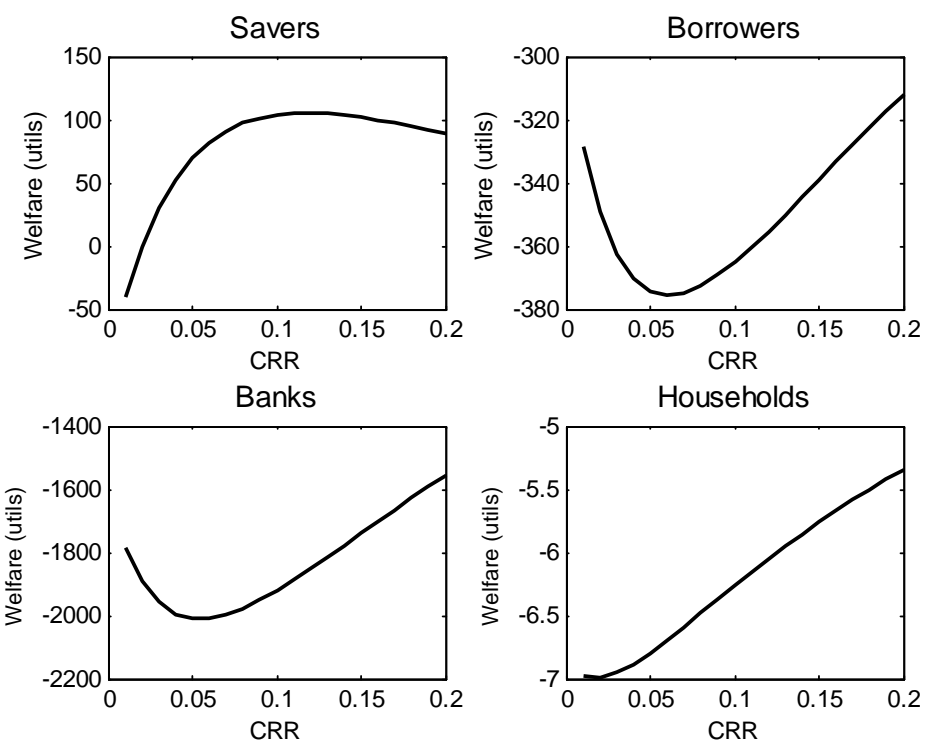

Figure 3: Welfare derived from increasing the capital requirement ratio (in utils).

countries' banks and related financial institutions.

However, the Basel III accord does not fully specify the criteria to change the capital requirement or under which specific conditions. There are, nevertheless, several things that we can infer from the Basel III statement:

-The countercyclical buffer is a macroprudential policy that uses the capital requirement ratio as an instrument.

-The main objective of this buffer in Basel III is to avoid excessive credit growth.

-The regulator should also use macroeconomic variables as indicators of excessive credit growth as well as the credit growth itself.

Thus, along these lines, we propose a rule on the capital requirement ratio that includes credit growth, house prices and output in order to explicitly promote financial stability. For the choice of the variables to be considered in the rule, we have followed the guidance stated by the IMF, the Committee on the Global Financial System, and the Basel Committee on Banking Supervision. The IMF (2013) states that a rise in house price can act as a leading indicator of excessive credit growth since they lead to wealth effects that permit the increase in borrowing. This wealth effect is present in our model through the collateral constraint for borrowers. The Committee on the Global Financial System (2012) identifies real estate prices as a potential indicator that could guide the build-up of capital-based instruments. In the same document, this Committee remarks the importance of variables such as real GDP growth 
and real estate prices in the stress tests that "can provide quantitative guidance on how capital levels should be adjusted." In turn, the Basel Committee on Banking Supervision, in its "Guidance for national authorities operating the countercyclical capital buffer" (2010), recommends to consider credit variables as well as a broad set of information to take buffer decisions in both the build-up and release phases. Some examples of variables that may be useful indicators in both phases include various asset prices and real GDP growth.

In this way, the countercyclical capital buffer would be implemented as a simple rule, in the spirit of the Taylor rules used for monetary policy. ${ }^{26}$

$$
C R R_{t}=\left(C R R_{S S}\right)\left(\frac{B_{t}}{B_{t-1}}\right)^{\phi_{b}}\left(\frac{Y_{t}}{Y}\right)^{\phi_{y}}\left(\frac{q_{t}}{q}\right)^{\phi_{q}}
$$

This rule states that whenever regulators observe that credit is growing, or output and house prices are above their steady-state value, they automatically increase the capital requirement ratio to avoid an excess in credit. Then, this rule captures the macroprudential approach of Basel III so that it anticipates credit growth and avoids it before hand, and it uses the capital requirement ratio as an instrument to achieve this goal. The goal is explicitly embedded in the rule since capital requirements respond directly to credit growth. This macroprudential rule also includes other macroeconomic variables that can be seen as indicators of credit growth such as output and house price deviations from their respective steady states. $^{27}$

Then, we study what the optimal implementation of the macroprudential countercyclical capital buffer would be, that is, the one that would maximize welfare.

\subsection{Optimal Parameters}

Table 4 presents the optimal parameters in equation (25) that maximize social welfare and compare results in terms of welfare gains with respect to the benchmark (no regulation, that is, there is no capital requirement).

We see that under Basel I and II (first column), only savers benefit from higher capital requirements, with respect to the no regulation situation. The second column shows the increase in capital requirements

\footnotetext{
${ }^{26}$ Note that the Taylor rule for monetary policy uses the interest rate as an instrument and it responds to output an inflation.

${ }^{27}$ We have also experimented with a symetric countercyclical rule for the LTV to compare the two instruments. In order to make both rules comparable, we have set all the reaction parameters equal to 0.5. We find that a comparable countercyclical rule for the LTV is more effective than the CRR rule in terms of increasing financial stability. In terms of welfare trade-offs, both rules deliver similar qualitative results.
} 
stated in Basel III without taking into account the countercyclical capital buffer. We find that increasing the capital requirements as in Basel III makes everyone better off with respect to Basel I, II. Therefore, Basel III, with no countercyclical buffer, already represents a welfare improvement with respect to Basel I, II.

Albeit, optimally implementing the countercyclical capital buffer, that is the third column named Basel III ${ }^{M P}$, manages to increase total welfare with respect to a situation of no regulation. Nevertheless, the losers in this case are the savers. Savers are better off with increases in the static capital requirement ratio but not with the countercyclical buffer, since it implies higher spreads. However, the countercyclical buffer provides a more stable financial scenario, as it can be inferred from the volatility of borrowing. Both borrowers and banks benefit from this measure because it helps them both smooth their consumption and reduce the collateral distortions that affect them. Savers, who are not collateral constrained, do not benefit from this scenario.

In terms of the optimal implementation of the rule, we observe that the regulator should attach relatively more weight to the output and the house price parameters in the rule, rather than to the credit growth parameter. The reason is that these variables serve as an anticipated indicator of credit growth and, therefore, help the regulator achieve its macroprudential goal; when the regulator observes credit growth itself, it may be too late to avoid it.

Table 4: Optimal Implementation of Basel III

\begin{tabular}{cccc}
\hline \hline & Basel I, II & Basel III & Basel III $^{M P}$ \\
\hline \hline$C R R_{S S}$ & $8 \%$ & $8 \%+2.5 \%$ & $8 \%+2.5 \%$ \\
$\phi_{b}^{*}$ & - & - & 0.1 \\
$\phi_{y}^{*}$ & - & - & 1.9 \\
$\phi_{q}^{*}$ & - & - & 1.6 \\
\hline \hline Welfare gain & & & \\
\hline \hline Savers & 2.97 & 3.29 & -0.88 \\
Borrowers & -0.58 & -0.49 & 2.61 \\
Banks & -0.99 & -0.98 & 1.58 \\
Total & -0.99 & -0.96 & 4.61 \\
\hline \hline Volatility of Borrowing & & & \\
\hline \hline STD (B) & 4.46 & 4.11 & 2.18 \\
\hline
\end{tabular}



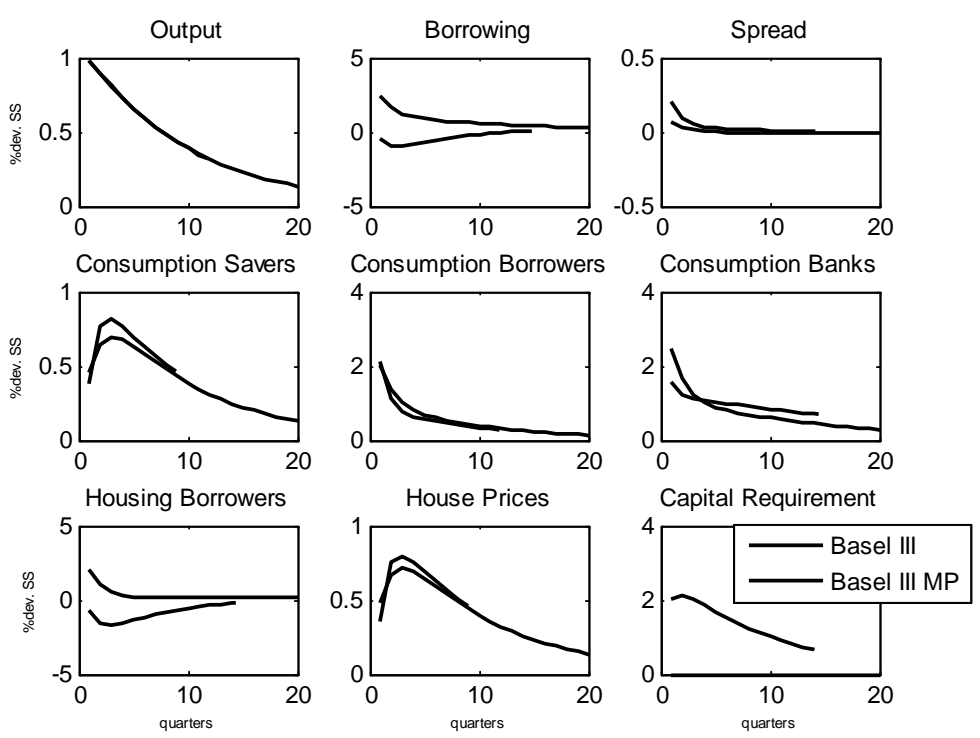

Figure 4: Impulse responses to a technology shock. Basel III versus Basel III ${ }^{M P}$.

\subsection{Simulations}

Here, we simulate the model for the Basel III requirements compared with Basel III ${ }^{M P}$ to study the procyclicality of regulations, a much discussed topic in the literature. Basel III require a total capital of 10.5\%. In order to simulate Basel $\mathrm{III}^{M P}$, we also consider a capital requirement of $10.5 \%$ in the steady state, together with the optimal macroprudential rule found in the previous section for the capital buffer. Notice, that this section is positive, describing the dynamics of the model. The previous section was normative, studying welfare.

Figure 4 presents the model impulse responses to a technology shock for the two alternative scenarios: Basel III and Basel III ${ }^{M P}$. Observe that these impulse responses are showing the pattern of the variables following a shock, that is, their deviations from their steady state. Note that welfare calculations (Table 4) show second order approximations, that is, volatilities which can be used for normative evaluations. Thus, Figure 4 and Table 4 are not directly comparable.

We see that under Basel III ${ }^{M P}$, following the technology shock, the capital requirement increases about $2 \%$ with respect to its steady state, while it remains at the steady state under Basel III. This higher capital requirement under Basel III ${ }^{M P}$ makes borrowing not to increase as much with the shock. Then, borrowers and banks can consume less under Basel III ${ }^{M P}$ but this is compensated by an increase in consumption by savers, which offsets aggregate differences. In terms of procyclicality of the regulation, we add to the discussion by disaggregating the effects among different agents. Our results show that 
the impact of this measure are countercyclical for the agents directly affected by the capital requirement ratio, i.e. borrowers and banks, while procyclical for savers.

\section{Concluding Remarks}

In this paper, we take as a baseline a dynamic stochastic general equilibrium (DSGE) model, which features a housing market and a financial intermediary, in order to evaluate the welfare achieved by Basel I, II, and III regulations. Therefore, in the model, there are three types of agents: savers, borrowers and banks. Borrowers are constrained in the amount they can borrow. Banks are constrained in the amount they can lend, that is, there is a capital requirement ratio for banks.

First, we evaluate how the model responds to changes in the capital requirement ratio from a positive point of view. We observe that higher capital requirements decrease the quantity of borrowing in the economy and, as a consequence, both borrowers and banks can consume less. This is offset by higher consumption by savers.

Then, we calculate the welfare effects of increasing the capital requirement ratio on the different agents of the model. Our results show that there is a welfare trade-off between borrowers and savers. While savers are better off when banks are required to hold more capital, borrowers and banks are initially worse off with this measure. On the one hand, increasing the capital requirement does not allow them borrow and lend as much as they would like, respectively, and, therefore, their consumption decreases. This is the level effect that affects them negatively. However, given binding constraints, the financial system is more stable with higher capital requirements. For larger values of the capital requirement ratio, this volatility effect coming from a second-order approximation, which makes their consumption more stable, prevails and both borrowers and banks end up being better off. For savers, this implies a higher pattern of consumption because in equilibrium, when borrowing decreases, they do not need to save as much.

After that, we propose a macroprudential rule for the capital buffer of Basel III (Basel III ${ }^{M P}$ ). With this rule, capital requirements would respond to credit growth, output and house prices. We find the optimal parameters of the rule that maximize welfare. The regulator should attach relatively more weight to the output and the house price parameters in the rule, rather than to the credit growth parameter, given that they serve as an anticipated indicator of credit growth. In terms of welfare, we see that the macroprudential component of Basel III ${ }^{M P}$ delivers higher welfare for the society than a situation with 
no regulation.

Finally, using the optimized parameters, we simulate the model to study the procyclicality of Basel III ${ }^{M P}$, a much discussed topic in the literature. We observe that, after a technology shock, capital requirements increase under Basel $\mathrm{III}^{M P}$. This macroprudential rule cuts borrowing, achieving the goal of the regulation, which is to avoid excessive credit growth. We add to the discussion finding that Basel $\mathrm{III}^{M P}$ is countercyclical for borrowers and banks, the agents directly affected by capital requirements, while procyclical for savers. 


\section{Appendix}

Steady-State of the main model

$$
\begin{aligned}
& C_{s}+D=R_{s} D+W_{s} N_{s}, \\
& R_{s}=\frac{1}{\beta_{s}} \\
& \frac{q H_{s}}{C_{s}}=\frac{j}{\left(1-\beta_{s}\right)} \\
& W_{s}=\left(N_{s}\right)^{\eta}-1 C_{s} \\
& C_{b}=\frac{\beta_{s}-1}{\beta_{s}} B+W_{b} N_{b}, \\
& B=\beta_{s} k q H_{b}, \\
& \lambda_{b}=\left(\beta_{s}-\beta_{b}\right), \\
& \frac{1}{C_{b}}\left(q-\left(\beta_{s}-\beta_{b}\right) \beta_{s} k q-\beta_{b} q\right)=\frac{j}{H_{b}}, \\
& W_{b}=\left(N_{b}\right)^{\eta}-1 C_{b}, \\
& C_{f}+B_{t}=\frac{\beta_{s}-1}{\beta_{s}} D+R_{b} B, \\
& \frac{D}{B}=\gamma, \\
& \lambda_{f}=\left(\beta_{s}-\beta_{f}\right), \\
& \frac{1-\gamma\left(\beta_{s}-\beta_{f}\right)}{\beta_{f}}=R_{b},
\end{aligned}
$$




$$
\begin{gathered}
Y=A N_{s}^{\alpha} N_{b}^{1-\alpha} \\
W_{s}=\alpha A\left(\frac{N_{s}}{N_{b}}\right)^{\alpha-1}, \\
W_{b}=A(1-\alpha)\left(\frac{N_{s}}{N_{b}}\right)^{\alpha} .
\end{gathered}
$$




\section{References}

[1] Acharya, V. V. (2009), 'A Theory of Systemic Risk and Design of Prudential Bank Regulation', Journal of Financial Stability, 5(3), pp. 224-255

[2] Admati, Anat R. and DeMarzo, Peter M. and Hellwig, Martin F. and Pfleiderer, Paul C., (2013). "Fallacies, Irrelevant Facts, and Myths in the Discussion of Capital Regulation: Why Bank Equity is Not Socially Expensive. "Max Planck Institute for Research on Collective Goods 2013/23; Rock Center for Corporate Governance at Stanford University Working Paper No. 161; Stanford University Graduate School of Business Research Paper No. 13-7.

[3] Adrian, T., and A. Ashcraft (2012). "Shadow Banking: A review of the literature," Unpublished working paper, Federal Reserve Bank of New York State Report No. 580.

[4] Agénor, P., Pereira da Silva, L., (2011), Macroeconomic Stability, Financial Stability, and Monetary Policy Rules, Ferdi Working Paper, 29

[5] Aikman, D, Haldane, A G and Nelson, B (2010), 'Curbing the credit cycle', available at www.bankofengland.co.uk/publications/Documents/speeches/2010/speech463.pdf.

[6] Aikman, D, Nelson, B and Tanaka, M (2012), 'Reputation, risk-taking and macroprudential policy', Bank of England Working Paper No. 462.

[7] Angelini, P., Neri, S., Panetta, F., (2011), Monetary and macroprudential policies, Bank of Italy Working Paper

[8] Angeloni, I. and Faia, E. (2013). Capital regulation and monetary policy with fragile banks, Journal of Monetary Economics, Vol. 60, Issue 3

[9] Bank of England (2009), 'The Role of Macroprudential Policy', A Discussion Paper

[10] Bank of England (2011), 'Instruments of macroprudential policy', A Discussion Paper

[11] Basel Committee on Banking Supervision, (2010), "Guidance for national authorities operating the countercyclical capital buffer," Bank for International Settlement publication

[12] Basel Committee on Banking Supervision, (2010), "The Basel Committee's Response to the Financial Crisis: Report to the G20," < http://www.bis.org/publ/bcbs179.pdf> 
[13] Benigno, P., Woodford, M., (2008), Linear-Quadratic Approximation of Optimal Policy Problems, mimeo

[14] Bergin, P., Hyung-Cheol, S., Tchakarov, I., (2001), "Does exchange rate variability matter for welfare? A quantitative investigation of stabilization policies," European Economic Review, 51 (4), $1041-1058$

[15] Bianchi, J (2011), 'Overborrowing and systemic externalities in the business cycle', American Economic Review, Vol. 101, No. 7, pages 3,400-26.

[16] Borio, C. (2003). Towards a macroprudential framework for financial supervision and regulation? BIS Working Paper No 128, February.

[17] Borio, C. (2011). Rediscovering the macroeconomic roots of financial stability policy: journey, challenges and away forward. BIS Working Papers No 354, September.

[18] Brunnermeier, M., Crockett, A., Goodhart, C., Persaud, A. and Shin, H. (2009), 'The Fundamental Principles of Financial Regulation', Geneva Report on the World Economy 11, ICBM, Geneva and CEPR, London

[19] Clerc, L., Derviz, L., Mendicino C., Moyen S., Nikolov, K. Stracca, L., Suarez J., and Vardulakis, A., (2014) "The 3D Model: a Framework to Assess Capital Regulation," Economic Bulletin and Financial Stability Report Articles, Banco de Portugal, Economics and Research Department.

[20] Committee on the Global Financial System (2012), "Operationalising the selection and application of macroprudential instruments," CGFS Paper No 48

[21] Domeij, D., Flodén, M., (2006) "The Labor-Supply Elasticity and Borrowing Constraints: Why Estimates are Biased." Review of Economic Dynamics, 9, 242-262

[22] Faia, E., Monacelli, T. (2007), "Optimal interest rate rules, asset prices, and credit frictions," Journal of Economic Dynamics and Control, 31 (10), 3228-3254

[23] Giese, Julia, Benjamin Nelson, Misa Tanaka and Nikola Tarashev (2013) How could macroprudential policy affect financial system resilience and credit? Lessons from the literature, Financial Stability Paper Bank of England, No. 21 - May 2013 
[24] Iacoviello, M. (2005), "House Prices, Borrowing Constraints and Monetary Policy in the Business Cycle." American Economic Review, 95 (3), 739-764

[25] Iacoviello, M. (2015), "Financial Business Cycles", Review of Economic Dynamics, Vol. 18, Issue 1, 140-163

[26] Iacoviello, M. and Neri, S. (2010), "Housing Market Spillovers: Evidence from an Estimated DSGE Model," American Economic Journal: Macroeconomics, 2, 125-164.

[27] IMF, Monetary and Capital Markets Division, (2011), Macroprudential Policy: An Organizing Framework, mimeo, IMF

[28] IMF, (2013). "Key Aspects of Macroprudential Policy: Background Paper," IMF Working Paper

[29] Jiménez, G., Ongena, S., Peydro , J. and Saurina, J. (2014). "Macroprudential Policy, Countercyclical Bank Capital Buffers and Credit Supply: Evidence from the Spanish Dynamic Provisioning Experiments." European Banking Center Discussion Paper No. 2012-011.

[30] Kannan, P., Rabanal, P. and A. Scott, (2012): "Monetary and Macroprudential Policy Rules in a Model with House Price Booms", The B.E. Journal of Macroeconomics, Contributions, 12 (1)

[31] Kant, R. and Jain, S., (2013), "Critical assessment of capital buffers under Basel III", Indian Journal of Finance, Vol. 7, Issue 4

[32] Kim, J., Ruge-Murcia, F., (2009), "How much inflation is necessary to grease the wheels?," Journal of Monetary Economics, 56 (3), 365-377

[33] Lawrance, E., (1991), "Poverty and the Rate of Time Preference: Evidence from Panel Data", The Journal of Political Economy, 99 (1), 54-77

[34] Longworth, D. (2011), 'A Survey of Macro- prudential Policy Issues', Mimeo, Carleton University

[35] Lorenzoni, G (2008), 'Inefficient credit booms', Review of Economic Studies, Vol. 75, No, 3, pages $809-33$.

[36] Mendicino, C., Pescatori, A., (2007), Credit Frictions, Housing Prices and Optimal Monetary Policy Rules, mimeo 
[37] Official Journal of the European Union (14-02-2012). RECOMMENDATION OF THE EUROPEAN SYSTEMIC RISK BOARD of 22 December 2011 on the macroprudential mandate of national authorities

[38] Official Journal of the European Union, (15-06-2013). RECOMMENDATION OF THE EUROPEAN SYSTEMIC RISK BOARD of 4 April 2013 on intermediate objectives and instruments of macroprudential policy

[39] Pintus, Patrick A. \& Wen, Yi \& Xing, Xiaochuan, 2015. "Interest Rate Dynamics, Variable-Rate Loan Contracts, and the Business Cycle," Working Papers 2015-32, Federal Reserve Bank of St. Louis.

[40] Repullo, R. and Suarez, J. (2013), "The procyclical effects of bank capital regulation", Review of Financial Studies, Vol. 26, Issue 2.

[41] Repullo, R. and Saurina, J. (2012). The Countercyclical Capital Buffer of Basel III: A Critical Assessment. In the Crisis Aftermath: New Regulatory Paradigms. Edited by Mathias Dewatripont and Xavier Freixas. Centre for Economic Policy Research (CEPR), London

[42] Rubio, M. (2011), Fixed- and Variable-Rate Mortgages, Business Cycles, and Monetary Policy, Journal of Money, Credit and Banking, Vol. 43, Is. 4

[43] Rubio, M. (2014), Housing Market Heterogeneity in a Monetary Union. Journal of International Money and Finance, Vol. 40.

[44] Rubio, M. and Carrasco-Galllego, J. (2014), "Macroprudential and Monetary Policies: Implications for Financial Stability and Welfare", Journal of Banking and Finance, 49, 326-336

[45] Rubio, M. and Carrasco-Galllego, J. (2015), "Macroprudential and Monetary Policy Rules: A Welfare Analysis", The Manchester School, Vol. 83, No. 2, 127-152

[46] Schmitt-Grohe, S. and Uribe, M. (2004), "Solving Dynamic General Equilibrium Models Using a Second-Order Approximation to the Policy Function," Journal of Economic Dynamics and Control, $28,755-775$ 